\title{
Use of the Suburban Forest Areas for Outdoor Activities
}

\author{
Karin Baisová and Martina Babiaková
}

\begin{abstract}
The presented paper addresses the use of accessibility in the area of the town Levoča for the development of tourism and sport activities proposing hiking trails and other facilities suitable for outdoor activities. The researched area is located in suburban forests around the town of Levoča, which territory falls within the Forest Management Unit (FMU) of Levoča and has geomorphological location in the Levoča Mountains. Transport accessibility of this territory and the status of tourist use of the area has been mapped and analysed by field work. In this area there are located 48 liner transport communications at a density of $\mathbf{4 2 . 1 5}$ m.ha-1. After analysing the current state of accessibility, a proposal of routes for tourist use has been designed. The use of existing tourist area was accompanied by proposals for 13 new routes with the total length of $94.5 \mathrm{~km}$, suitable for various physical activities, such as hiking, biking, horse riding, roller skating and/or cross country skiing. The proposal was accompanied by other service facilities such as a recreation centre, boarding facility, parking or small recreational buildings to increase the attractiveness and thus the competitiveness of the territory.
\end{abstract}

Index Terms-Forest environment, hiking trails, physical activity, transport accessibility.

\section{INTRODUCTION}

Modern way of life shifts people to continual lowering of stimuli which lead to active physical activity. Lack of movement results in low physical and mental ability which influences the organism's activity in a rather negative way [1] According to literature [2] starting already at basic school education, teachers have a challenging job to bring up children and generations that will become a promise for better future within the society.

Physical activity as a basic functional feature and an existential human need, is an important recreational, sport, relaxation, fitness, and under certain conditions, also a cultivation factor in each age. "Variety of physical outdoor activities means for people a diverse load of intensity from low to heavy load which results into various levels of energy use [3]. This has according to literature [4] a positive influence on human organism from the point of view of internal load on increasing fitness levels and improving health. The choice of physical activities depends mostly on morphological and climate conditions of the area, distance and attractiveness, as well as the interest to support certain specific forms of physical activities [5].

From this unfolds also the structure, type and nature of routes for physical activities, service facilities and their end points, and also the extent and methods of physical activity regulations. Walking, if possibly horse riding is the least

Manuscript received January 29, 2016; revised April 12, 2016.

The authors are with the Institute of Physical Education and Sport, Technical University in Zvolen, Slovakia (e-mail: karin.baisova@tuzvo.sk, martina.babiakova@tuzvo.sk). limitable for space and the least challenging for proposing the routes. Exercise on bikes nevertheless requires at least some technically modified routes. The advantage is, that the routes for such physical activity are directional and structurally relatively simple and almost always useful and multi-purpose. But this can also be a problem, because especially for users' security, using such routes requires certain restrictions and regulations. Of the many physical activities, these deserve such support especially when used collectively, since they have a significant regional impact, and must be universally accessible as public roads.

Each physical activity has its specific requirements for technical parameters of a route, mainly the type and quality of its surface, direction changes, and altitude differences, for adjustments along the route and for the operational and maintenance facilities. The most important tool for guiding and locating movement of such sites in forests is a forest road network. Its importance has increased after changes in legislation. By adjusting the Forest Act (325/2005 Coll., Act 360/2007 Coll.) certain physical activities were restricted, or regulated. In $\S 31$ par. 1 point. d) as follows: "It is forbidden to drive or stand with a motor vehicle, scooter, motor tricycle or quadric cycle on the forest land which is outside the marked areas", as amended: "and ride a bike or ride on horseback outside the designated forest road."

According to literature [6] only few people are interested in outdoor physical activities, e.g. in hiking. We think that actually not knowing the environment can be the cause of this unfavourable situation. Therefore we believe that mapping the area and designing the tourist routes can lead to the fact that families with children from the Levoča region as well as its visitors could use the area for beneficial physical activities such as hiking or biking. Therefore the aim of the project was the proposal for using this tourist area - suburban forests in the town of Levoča. One part of the objective was to analyse the transport accessibility of the territory and its potential for tourist use. Based on the evaluation of the current state another partial design of optimization of the existing systems was proposed, adding new scheduled routes designed for various suitable types of tourist physical activities.

\section{Methodology}

The proposed project is being solved in the suburban forests around Levoča, which are managed by the company Forests of the Town of Levoča, Ltd. in the area of 6,139 ha. Due to the large area of suburban forests, its northern part became our main area of interest, which is on larger scale used for recreational purposes by general public. The area is a part of the Forest Management Unit (FMU) of Levoča town, which geomorphological region falls within the Levoča Mountains. The area borders with the northern edge of the town, the southern boundary of the former military training 
area Javorina and eastern part of the villages Závadza and Úloža.

Within the project we evaluated transport accessibility of the area as the main design instrument of linear hiking trails. This was conducted by fieldwork research where all roads and trails located in the area were mapped, their technical conditions were researched. Transport accessibility of the forest complex is managed by forest roads, which have the character of either so called outgoing forest communications or skidding forest roads. Outgoing forest communications form the main skeleton accessibility of the forest and are determined in terms of forestry production, particularly for wood transportation by roadside kit and they are the best quality forest roads and have also the character of carriage roads. In terms of use they are intended either for all year round traffic or seasonal use (vegetation period). Skidding forest roads are used for transporting wood from the forests to the skid road with proximity means (e.g. tractors), these are usually unpaved natural roads without a carriage road. In forests there can also be present so called unknown roads, e.g. roads that pass through a forest complex, not owned by forestry subjects, but they may be used for various activities (e.g. national roads). Except of its main function transportation of wood, forest roads have also a number of other functions, including recreational function. In terms of the research it was important to identify appropriate communication to design tourist routes, in terms of localization, aesthetic integration into the landscape, roads amenities for aesthetic elements, slope conditions, the type of road surface, technical conditions or their level of damage.

The degree of accessibility of the area was mapped according to technical standards STN 736801 Forest Road Network. When assessing technical conditions in terms of damage of the road surfaces, the roads were classified into five levels of disturbance [7]. One part of the fieldwork research was also to map the hiking and sport activities, the current state of existing hiking trails and to specify the recreational potential of the area.

Based on the outcome of the fieldwork research there was drawn up a proposal solution of using the tourist area from the point of view of various hiking trails suitable for a variety of physical activities and various criteria for planning and routing were taken into account. In terms of orientation, routes or their parts have been proposed either intended for only one type of activity, or as multi-functional, for a variety of activities, where the risk of conflict among users is minimal. In terms of performance, routes have been specified by undemanding routes of recreational character to a sophisticated, sport character. In the design of each track important factors were the type and the quality of the surface, which takes into account the requirements of each proposed activity.

The design of routes is the nature of the study, as the designs of the routes were conducted on the existing roads, so it was a route proposal without any structural modifications, with the exception of few proposals for necessary adjustments and repairs to concrete roads, in order to serve the project purpose. In the proposal of particular routes were used the design methodologies of hiking trails by Gebhard [8]. Part of the project was also a proposal to build accommodation facilities, parking spaces, small buildings of recreational character as the part of the route facilities (e.g. benches, shelters, information boards, direction signs, etc.).

\section{RESUlts AND DiscUSSION}

\section{A. Traffic Accessibility Analysis}

The area can be characterized by good transport access; there are 48 traffic roads (41 roads and 7 footpaths) with a total length of $98 \mathrm{~km}$. According to the representation of the individual types of roads, timber transport roads, some involving other roads (state-owned roads of the 3rd class) make up $43 \%(42.3 \mathrm{~km})$, skidding natural roads represent $49 \%$ $(47.9 \mathrm{~km})$ and walking paths count for $8 \%(78 \mathrm{~km})$. In total the density of transport communications is $42.15 \mathrm{~m} . \mathrm{ha}^{-1}$. In terms of the surface, $23.7 \mathrm{~km}$ of roads are with bituminous finishing, $8.9 \mathrm{~km}$ of roads with grit finishing, and the remaining $57.6 \mathrm{~km}$ of roads and $7.8 \mathrm{~km}$ of walking paths have soil surface.

The field research reveals some general conclusions concerning the essential characteristics of the roads. In terms of the road surface half of all roads are natural $(50.8 \%)$, roads with gravelled carriage road represent $10.4 \%$. Relatively high proportion of roads is with the highest quality bitumen road $(39.0 \%)$, these are especially other roads (state-owned roads of the 3rd class).

Based on the ranking of the roads technical conditions according to the level of damage, in the best technical conditions had forest roads with bitumen cover (mostly the 1st level of deformation). Forest seasonal timber transport roads had mostly 2 nd -3 rd grade of violation. Intermediate or catastrophic level of violation is more than $53 \%$ and it applies particularly to natural forest skidding roads. Technical condition of roads had an importance in the classification of particular communication into the system of the proposed hiking trails. Therefore, in this case there was suggested to repair or necessarily to reconstruct these roads.

\section{B. Analysis of Tourist Use of the Area}

Existing tourist and recreational activities in the area are located in the following three main centres:

1) Mariánska hora Mountain in Levoča - one of the most important religious pilgrimage places in Slovakia with ancient history dating from 1247, famous for the visit of the Pope John Paul II on his pilgrimage in 1995. There is a building of basilica and a wooden chapel, which complements the network of walk paths, alleys, garden houses, rest areas, benches, toilets etc. This location is also a popular place for paragliding.

2) Recreation area Kováčová Vila (guest house) - located 3 $\mathrm{km}$ to the north from the historic centre of Levoča situated near the homonymous water reservoir. Part of the facility is also an apartment-hotel with a car camping site used for summer recreation - swimming, water sports, fishing and hiking.

3) Ski Centre Levoča - winter sport resort located in the suburban area of Levočská dolina (valley), $6 \mathrm{~km}$ north from Levoča, at an altitude of 634 - 876 meters above sea level. It offers 4 slopes of all difficulty levels with a total length of 2,400 m, 4 ski lifts with a total length of 1,833 $\mathrm{m}$ with capacity of 2,500 people per hour and 2 cross - 
country trails with the length of 10 and $3.5 \mathrm{~km}$. The resort is also suitable for accommodation and as a parking facility.

From the point of view of the existence of linear paths of individual physical activities in this area, these include mainly trails for hikers and bicycle paths. In this area there are four hiking trails that are outlined in the concept of the Slovak Tourist Union and are marked on tourist maps:

1) Blue trail: Levoča - Mariánska hora (mountain) Diablov Vrch (hill) - Levočská Dolina (valley), time 2.20 hours, length of the route $-7 \mathrm{~km}$, demanding trail.

2) Yellow trail: Levočská Dolina (Kováčova vila) - Marian Hill, 2.6 kilometers, easy trail,

3) Green trail: Levoča - Zbojnícka lúka, 1.30 hours, 4 km, difficulty of the trail- intermediate. In parallel with this there is also a biking trail.

4) Red trail: trail, which passes through the area in the direction of Zbojnícka lúka (medow) - Levočská Dolina (valley), Kováčová vila (guest house) - Úloža, 3.00 h, $10 \mathrm{~km}$. Nice hiking trail in the southwestern part of the Levoča Moutains, part of the route is also suitable for mountain bikes and skiing. In terms of routes passing through the area is Levoča Cycling Trail of the length of $41 \mathrm{~km}$, which enables the crossing from Kežmarok to Levoča continuing near the valley of the Torysa River. Its route goes in the direction of Hradisko - Levoča (Partizánska cesta - road) - Levočská Dolina (Kováčová vila - ramp - settlement - Podhrby) - Závada - Vyšné Repáše - Nižné Repáše - Olšavica - Brutovce - Vyšný Slavkov. The route runs mostly on state-owned roads of the 3rd class and the nature of the road is a bicycle track.

\section{Proposed Trails for Physical Activities}

When designing the recreational use of the area, the starting point was the current state of recreation concentrating on the three above-mentioned centres. It was proposed as an extension to another location with a great potential - Kúty. It is a vast complex of meadows with nice prospect, good accessibility, both in the direction of Levoča and Úloža. There might be concentrated summer tourism with various attractions for children, with sport and relaxation zones. The proposal includes the construction of a larger complex that would include playgrounds for children, courts for ball games, rest areas, summer houses, fireplaces, toilets, and parking areas. Our intention in the design of individual routes was to achieve a connection between single centres with routes specific for various physical activities.

The main tool for designing the proposals was the availability of the area and its forest road network. The proposed routes were located on existing forest roads and trails to suit their technical conditions and to fulfil technical specifications required for the appropriate route types. As a part of the solution, there is also a proposal for the reconstruction of three affected forest roads designed for recreational use and the plan for repairs and maintenance of other roads. The effort was to adverse a collision risk groups of tourists (cyclists, horsemen) to minimize double use of the same routes with different types of physical activities at the same time, which on the other hand, excludes the multifunctional use of the same route with several physical activities where there is a minimum risk of collision or using it in different time periods (summer - winter).

Hiking trails have been designed for various physical activities such as hiking, cycling, roller skating, jogging, horseback riding and cross-country skiing in winter.

Within trails for hiking there were designed 4 routes with different difficulty levels, connected together with a selection or combination of the following routes:

1) Trail no. 1 Kováčova Vila (guest house) - Levočská Dolina (valley) - Cugová - Daní haz - Ku zlatej studni Diablov Vrch - Staňov - Kocúrová - village Úloža. This route for its modesty and without high climbing elements is designed for winter sports e.g. cross-country trails suitable for cross-country skiing.

2) Trail no. 2 Levoča (football field) - cottage area Regrunt - Pol'ačka - the proposed centre Kúty - Úloža.

3) Trail no. 3 Kocúrová - above the peak Zimná hôrka connection to route no. 2 below the location Kúty, as a connection route.

4) Trail no. 4 Levoča (suburb) - Miklerik - Zbojnícka lúka - Fedorkin jarok - connection to route no. 1 near the Levoča stream.

Winter tourism is represented by the design of already mentioned cross-country skiing trail, which follows the route no. 1 for hiking with favourable slope conditions and low terrain difficulty. For the purposes of roller skating there was designed the route from recreational facilities Kováčova vila (guest house) in the direction of Levočská Dolina (valley) to the main crossroad. The route can be characterized by favourable slope conditions, quality bitumen road finishing and minimum car traffic. This route can be utilized for its modesty and surface quality for other physical activities such as running, movement of pedestrians with strollers or disabled people.

Bicycle paths are based on the existing Levoča cycling trail, but focuse on mountain biking with various difficulty level at which there were designed three routes joined together with an option to choose a combination of the route:

1) Trail no. 1 Levoča (Košická Brána - gate) - cottage area Regrunt - Rovderka - Durst.

2) Trail no. 2 Levoča (Košická Brána - gate) - Úloža Kocúrová - above the peak Zimná hôrka - Kúty - Daní haz - Trubačka - Kováčova vila. This route leads from the village Úloža, in parallel with the already proposed hiking trail (no. 1 and 3 in the length of $1.8 \mathrm{~km}$ ) and then connects with the existing red tourist route through the site Kúty with the length of $2.2 \mathrm{~km}$.

3) Trail no. 3 introduces the connecting route of the previous two routes starting at the location Polačka and continuing towards the location of Druhá lúka.

Horse tracks in this area do not exist officially, but there are three breeding stations for riding horses in Levoča (northern suburb). Levočské Kúpele (spa) and Levočská dolina (valley) have plans for commercial development of equestrian tourism. For this purpose there were designed 4 horse tracks, which either connect the breeding stations together or have a character of circuits.

1) Route no. 1 is a circular trail leading from Levoča (breeding station) - through meadow vegetation underneath the Mariánska hora (hill) - to the water reservoir Kováčova vila (guest house) - and is leading back along to the breeding station in Levoča. 
2) Trail no. 2 connects two circular routes (no. 1 and 3). It starts at the crossroads near the water reservoir Kováčova vila (guest house), goes pass it - continues near breeding stations in the area of Levočské kúpele (spa) and Levočská dolina (valley) - next goes pass by Cúgová - to location Ku zlatej studni, where it joins route no. 3 .

3) Trail no. 3 is a circular trail in the direction $\mathrm{Ku}$ zlatej studni - Diablov vrch - Plazová - Diabla dolina - Slaná - Zákruty - Kocúrová - Úloža - Zimná hôrka - Kúty - starting point.

4) Trail no. 4 is a circular trail in the direction of Levoča (breeding station) - Miklarik - Zbojnická lúka connection to the red tourist route - trough meadow vegetation across the Levoča stream to the starting point.

Basic technical parameters of each track are listed in the Table I.

TABLE I: PROPOSAL OF DifFERENT TYPES OF ROUTES, WHERE E - EARTH, G - GRIT, A - ASPHALT

\begin{tabular}{|c|c|c|c|c|c|c|}
\hline Route & No. & Length (m) & Average slope $\%$ & Camber (m) & Difficulty & Cover Surface \\
\hline \multirow[t]{4}{*}{ Pedestrian } & 1 & 10,600 & 3.0 & 305 & low & grit \\
\hline & 2 & 6,300 & 5.2 & 295 & intermediate & e, $g, a$ \\
\hline & 3 & 1,400 & 7.1 & 55 & intermediate & Earth \\
\hline & 4 & 7,500 & 7.3 & 270 & low & Earth \\
\hline Cross - country & 1 & 10,600 & 3.0 & 305 & low & grit \\
\hline Roller skater & 1 & 3,200 & 2.0 & 20 & low & asphalt \\
\hline \multirow[t]{3}{*}{ Bicycle paths } & 1 & 8,200 & 6.0 & 225 & high & $\mathrm{e}, \mathrm{g}, \mathrm{a}$ \\
\hline & 2 & 15,200 & 5.7 & 395 & low & $\mathrm{e}, \mathrm{g}, \mathrm{a}$ \\
\hline & 3 & 2,000 & 6.3 & 135 & intermediate & $\mathrm{g}, \mathrm{a}$ \\
\hline \multirow[t]{4}{*}{ Horse tracks } & 1 & 5,600 & 7.0 & 185 & low & earth \\
\hline & 2 & 5,700 & 3.5 & 200 & intermediate & Earth, grit \\
\hline & 3 & 10,900 & 5.5 & 175 & intermediate & Earth \\
\hline & 4 & 7700 & 7.7 & 297 & intermediate & Earth \\
\hline
\end{tabular}

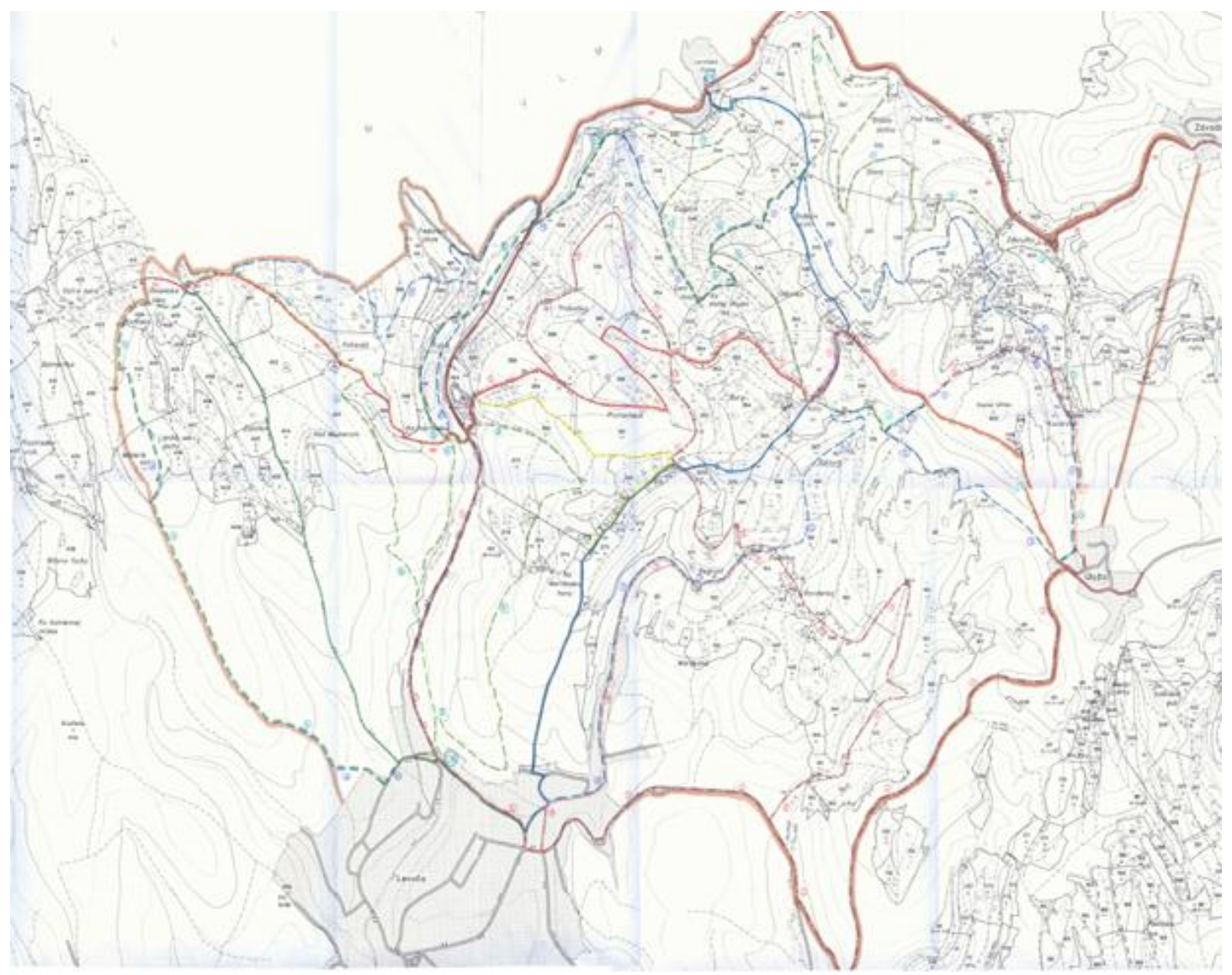

Fig. 1. Organization map of suburban forests around Levoča, FMU Levoča - the proposed hiking trails.

Fig. 1 depicts the map of suburban forests and Levoča town, where are clearly marked also the proposed hiking trails and routes. The design of routes is connected to the boarding place on the northern border of the town Levoča as a starting point from which the movement of tourists is directed to the designed area and it is also accompanied by a proposal for the building of parking space and small buildings of recreational character (notice board, direction signs, summer house, open seating, litter bins, toilets).

The main idea behind these proposals is to reduce the burden on the existing recreational facilities, to regulate the movement of tourists through the forest habitat or to increase recreational capacity and attractiveness of this area. It is important to combine the use of forest roads by forest management as well as for the purpose of recreation of the population. For that it is necessary to develop a system of 
operating rules on roads with recreational use, to avoid collision or disturbance of forest activities for recreation and vice versa.

\section{CONCLUSION}

Growing interest of population to visit forests leads also to an increasing demand to regulate and guide physical movement activities. An effective tool for planning tourist routes designed for different physical activities is the use of transport accessibility of the forest complex.

Based on the identified characteristics of the given territory, the current state of the tourist access and facilities of the territory - Forest Management Unit (FMU) in Levoča, there were designed 13 scheduled routes for different kinds of tourism with a total length of $94.9 \mathrm{~km}$ and a recreational centre. The new routes have been designed along with the already existing ones, and on the whole they are forming a comprehensive network so that tourists can select the best suitable route according to their interest. The proposal was supplemented by another proposal to equip the routes with other objects such as boarding place, relax areas and small structures in order to increase the level and the competitiveness of the area allowing visitors to enjoy the beauty of the nature.

When sharing the same space in a forest area, it often leads to conflicts of interest. It is on one hand among individual modes of tourism, but on the other hand there is often a conflict of interest between tourists and forest managers, particularly because of the frequent and dangerous confrontation of tourists and vehicles of forestry service. Problematic are also conflicts of interest among hunters and tourists, because of the distraction of animals and hunting grounds. Similar problems are also in relation with agricultural land managers. Such conflicts can though be eliminated by mutual agreement, by communication of the parties involved and the appropriate combination of legislative measures.

\section{ACKNOWLEDGMENT}

The presented paper is being published with the support of the IPA Project No. 14/2015.

\section{REFERENCES}

[1] B. Bet'ák, "Vol'nočasové aktivity žiakov a žiačok stredných škôl na strednom Slovensku so zameraním na zimné sporty," presented at the Šport a športový tréning, Trenčín, Trenčianska univerzita Alexandra Dubčeka v Trenčíne, April 10, 2015.

[2] S. Azor and L. Opáth, "Úroveň špeciálnej pohybovej výkonnosti so zameraním na volejbal u chlapcov a dievčat bežnej rómskej populácie na 1. Stupni ZŠ,” presented at the Pohybová aktivita, šport a zdravý životný štýl, Trenčín, Trenčianska Univerzita Alexandra Dubčeka v Trenčíne, June 19-20, 2013.
[3] M. Kučera and J. Popelka, "Vplyv zat'aženia v kurzoch plážového volejbalu na študentov telesnej výchovy," presented at the Pohybová aktivita v živote človeka - Pohyb detí, Prešov, Prešovská univerzita v Prešove, November 26-27, 2010.

[4] J. Popelka, "Odozva srdcovej frekvencie na herné zat’aženie v plážovom volejbale," Telesná výchova and Šport, vol. 25, pp. 29-31, January 2015

[5] S. Azor and V. Juško, "Realizácia projektu IPA 14/2015 Implementation of the project Accessing the selected location VšLP area of interest for the purpose of recreational use," presented at the Telesná výchova a šport v živote človeka, Zvolen, TUZVO, September 10-11, 2015

[6] J. Popelka, "Opinions and interests of primary school students in physical education," Acta Universitatis Matthiae Belii: Physical education and sport, vol. 2, pp. 102-108, November 2010

[7] K. Gebhard, et al. (January 2015). Príručka pre prípravu interpretačných chodníkov. Ekologický turizmus v Európe. Bonn. [Online]. http://www.oete.de/dokumente/36_trail_planning_guide_sk.pdf

[8] P. Klč and A. Králik, Katalóg Porušení A záVAD Na Lesných CestÁch, Bratislava: Príroda, 1991, pp. 37-38.

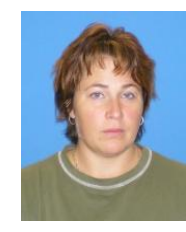

Karin Baisová is a $\mathrm{PhD}$, the Institute of Physical Education and Sport, Technical University in Zvolen, Masarykova 24, 96053 Zvolen, Slovak Republic.

She was born in Banská Bystrica (Slovak Republic) on in 1973. In 1996 she graduated MSc. of Humanities from the Matej Bel University in Banská Bystrica, where she studied Physical Education and Pedagogy. In 2008 she finished her $\mathrm{PhD}$ studies in Physical Education.

Since 1997 she worked as an assistant professor at the Department of Physical Education at the Pedagogical Faculty at the Matej Bel University. Her main scope of pedagogical and research activity was sport games and physical activities for kindergartens.

Since 2007 she has continued her professional carrier at the Technical University in Zvolen at the Institute of Physical Education and Sport. Her main activities are body building, fitness, aerobics, hiking, and specialized courses of physical education. These areas are also the main scope of her research activities and publications.

Dr. Baisová is active in Senior University at the Technical University in Zvolen as a lecturer and also guaranties the study program Sport for Health

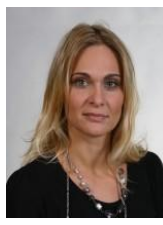

Martina Babiaková is with Institute of Foreign Languages, Technical University in Zvolen, Masarykova 24, 96053 Zvolen, Slovak Republic. She was born in Zvolen (Slovak Republic) in 1976. In 1999 graduated with MSc. of Humanities from the Matej Bel University in Banská Bystrica where she studied English Language and Literature. In 2009 she finished her rigorous degree with the academic title Doctor of Pedagogy.

Since 1999 she has worked as an assistant proffessor at the Institute of Foreign Languages at the Technical University in Zvolen, Slovak Republic. Her main responsibilities are teaching Business and ESP English mostly in the areas of forestry, woodworking industry and ecology. She is active in institutional research projects and activities. She translates as well as interprets at conferences and symposiums, acts as an invigilator for international language examinations and publishes as a co-author in a variety of research areas within the scope of the Technical University in Zvolen. Presently she is engaged in the institutional research team in the project of Implementing Electronic Materials in Foreign Language Teaching at the Technical University in Zvolen.

Dr. Babiaková is a member of TESOL International, is responsible for foreign language section of Student Scientific International Conference at the Technical University in Zvolen. 